\title{
Does Demutualization Spur Liquidity?
}

\author{
Farman Ali $* 1$, Man Wang ${ }^{2}$, Imran Ali ${ }^{3}$, Syed Tauseef Ali 4 \\ ${ }^{1}$ Dongbei University of Finance and Economice, Dalian China \\ 2 School of Accounting, Dongbei University of Finance and Economics Dalian China, \\ Internal Control Research Center in China \\ ${ }^{3}$ Department of Business Studies, Pakistan Institute of Development Economics, \\ Pakistan \\ ${ }^{4}$ School of Accounting, Dongbei University of Finance and Economics, Dalian China \\ * Corresponding author: farman.dufe@gmail.com
}

\begin{abstract}
Article History
Received 2019-12-18

Revised 2020-01-11

Accepted 2020-01-12

Published 2020-01-12
\end{abstract}

\section{Keywords}

Demutualization

Liquidity

Turnover

Amivest ratio

Bid-Ask Spread

\section{How to cite?}

Ali, F., Wang, M., Ali, I., \& Ali, S. T.

(2020). Does Demutualization Spur

Liquidity? SEISENSE Journal of

Management, 3(1), 15-26.

doi:10.33215/sjom.v3i1.278

\section{Abstract}

Purpose: The literature on demutualization is confined to efficiency and social welfare issues. Little empirical literature exists on the effect of demutualization on listed firms. This study examines the impact of demutualization on the liquidity of listed firms' stocks.

Methodology: It empirically investigates how the liquidity of listed firms' stocks is affected by demutualization. Analyzing data of 137 non-financial firms listed on the Pakistan Stock Exchange for 2005 to 2017, we employ fixed effect regression to test the hypotheses.

Findings: We find that demutualization has significantly improved liquidity. We analyze all three dimensions of liquidity that are the trading activity, market impact, and transaction cost. We find that demutualization increases trading activity, improve market depth, and has reduced the transaction cost.

Implications: Our findings suggest that demutualization is beneficial not only for listed firms but also for its shareholders as all three dimensions of liquidity are improved by demutualization. Stock exchanges that are not demutualized and are facing liquidity problem, can be improved by changing its structure from mutual to demutualized.

Originality: Prior literature focuses on the impact of demutualization on the stock market or social welfare. There is scares research on the effect of demutualization of the listed firm. This study fills this gap by analyzing the impact of demutualization on listed firms' liquidity in a developing economy, such as Pakistan. 


\section{Introduction}

Stock exchanges traditionally operated as non-profit or membership organizations. Decisions were made based on one-person-one-vote. There was no competition or regulations. The market makers or members of the exchange controlled the price, range of services, and quality of services produced by the stock exchange. Members had decision-making power, ownership, and trading rights. In mutual exchanges, ownership is not transferrable but is terminated if a member quit. These exchanges performed monopoly businesses on their local markets. Companies have no option but to list on their local exchange, and investors have the only option to invest their money in their local market. Since 1993 when the first stock exchange of the world, the Stockholm Stock Exchange, was demutualized, the business environment of stock exchange has been dramatically changed.

Moreover, this change is continued as more and more exchanges are getting demutualized. Through demutualization the non-profit member-owned exchanges are converted into for-profit investors-owned limited companies. Demutualization is motivated by globalization, technological advancement, regulatory reforms, and the introduction of new financial products. Due to the changing business environment for the stock exchange, they also needed to react accordingly, but it was not possible under the mutual structure.

More research is needed to identify how firms' stock liquidity is affected by demutualization, as this relationship is largely unidentified. There are both regulatory and economic aspects of demutualization which affect all stakeholders and the economy. Prior studies focused on either the regulatory issues connected to demutualization or on the relationship between demutualized exchanges and their financial performance. This paper explores the relationship between demutualization and stocks of listed firms traded on these converted exchanges. We focus on what firms gain from demutualization. This is the main question to be addressed in this study. This is done through empirically analyzing firms listed on Pakistan Stock Exchange Limited (PSX), which is demutualized in 2012.

Liquidity is important to be analyzed because it ultimately affects the cost of capital. It will be hard to sell a security that has low trading volume because it pushes the ask-bid spread to be high. This will be reflected in the prices; hence it makes the stock less desirable for investors. Amihud and Mendelson (1986) were among the pioneers who explore the relationship between bid-ask spread and stock returns and find that when the bidask spread is broader, investors will expect higher returns to compensate for the trading cost. The higher bidask spread will result in high volatility and low liquidity, which will push transaction cost higher. As a result, the market participants will expect higher returns to remunerate this higher transaction cost. Measuring liquidity through turnover rate, Datar, Naik, and Radcliffe (1998) found that liquidity significantly affects the variations in stock returns. Therefore, liquidity is important for both firms and stock exchanges on which they are traded.

This study aims to explore the relationship between demutualization and stock liquidity. This study sheds light on how firms gain from demutualization in terms of liquidity.

The rest of the paper is organized into different sections. Section 2 is the review of the literature regarding demutualization and its various implications. In section 3, we developed a hypothesis on the effect of demutualization on liquidity. Section 4 explains the methodology. Section 5 provides the empirical results, and we conclude the paper in section 6 .

\section{Literature Review}

The term demutualization is defined as the transformation of a non-profit entity owned by members to forprofit corporations owned by its investors (Karmel, 2000). The traditional mutual exchanges were run by members, and only they had access to the trading activities. Lee (1998) argued that members or brokers ran 
mutual exchanges, and investors have to pay a fee to these brokers for their services if they want to trade on the stock exchange. This made them resistant to change because their competitive position and source of revenue were at risk. The demutualization process often consists of four steps; the first one is to obtain the consent of regulatory bodies and government, then transferring rights of membership to shares, followed by the listing of exchange and public issuance, with eventual or immediate freely traded shares (Hughes \& Zargar, 2006). Since the inception of demutualization in 1993, a large number of stock exchanges around the globe have demutualized. These include stock exchanges of countries like the USA, UK, Australia, Singapore, Hong Kong, India, Japan, Malaysia, among others.

According to the report of the World Federation of Exchanges published in 2017, around 66\% of the world's exchanges have been demutualized. This percentage is expected to increase as more and more stock exchanges are planning to demutualize. Globalization and technological advancement have changed the traditional view of exchanges. The introduction of ECNs and computerized exchanges has eliminated the need for intermediation. It has limited the presence of brokers on the trading floor. Now investors are not obliged to go to the trading floor for listing and trading physically. These technological advancements have allowed investors to trade on exchanges throughout the globe. This increased the competition among exchanges, and to get the market share; they need to adapt to these changes. The traditional member-owned exchanges have many drawbacks as they are not flexible to the changing environment (Steil, 2002).

Demutualization literature is mostly composed of regulatory issues and the financial performance of exchanges. Analyzing the relationship between demutualization and stock exchange efficiency, Hart and Moore (1996) find a significant improvement in efficiency after the demutualization of the stock exchange. Steil (2002) is of the view that demutualization reduces the control of brokers. Cybo-Ottone, Di Noia, and Murgia (2000) argue that demutualized exchanges should run as a for-profit entity and should serve the interest of exchange rather than the interest of members. Aggarwal (2002) argues that these converted exchanges accompanied by a change in governance structure have to represent outside shareholders. Taking an example of three stock exchanges that were demutualized, Aggarwal (2002) find that the shares price performance of these exchanges is improving since the day of demutualization. The share price and the number of shareholders are increasing since the day exchanges became public companies.

Researchers also analyzed stock exchange performance after demutualization to found whether it is improved by demutualization. Krishnamurti, Sequeira, and Fangjian (2003) find that demutualization improves the market quality of stock exchanges. In their study, Schmiedel (2001) find that the demutualization of exchanges positively affects cost efficiency. These exchanges perform $20-25 \%$ better than the efficiency benchmark. Market size, change in the governance structure, trading services diversification, and adoption of new technology has a greater influence on trading services. Schmiedel (2002) finds that the European stock exchange has progressed in efficiency from 1993 to 1999. The introduction of new technologies, changes in governance structure, and innovation have resulted in greater growth in these stock exchanges. Due to improved governance and efficiency, the operating and market performance of demutualized stock exchanges have improved (Aggarwal \& Dahiya, 2006). Angel (2003) find that demutualized exchanges react faster to changes, and that is more cost-efficient for investors in trading. This is an advantage that demutualized exchange has over a mutual one. Considering the Australian Stock Exchange (ASE) merger as a case, Otchere and AbouZied (2008) argue that the trading activity and profitability ratios of the Australian Stock Exchange have improved with demutualization. In his study, Azzam (2010) find that demutualization enhances financial performance, liquidity, and size and reduces its debt. Padilla-Angulo and Ben Slimane (2018) argue that demutualization, when accompanied with a change in governance structure, improves the efficiency of exchanges. They also argue that demutualization ameliorates the reputation of stock exchanges. Analyzing demutualization's short and long term impact on the performance of stock exchanges, Slimane and Angulo 
(2018) find that it improves long term performance, while there is no significant improvement in performance in short-term. They also find that this enhanced performance is moderated by restructuring in corporate governance.

There is scarce literature, which focuses on the effect of demutualization on firms that are listed on these exchanges. Taking the case of Euronext merger Nielsson (2009) finds that stock liquidity of listed firms has increased after demutualization. However, this liquidity is asymmetrically distributed across firms. He argues that the liquidity of firms with foreign sales and large firms has significantly increased after the merger, while the merger does not significantly affect the liquidity of medium and small firms. Researchers also found no evidence in an increase in the liquidity of firms that operate domestically. Studying the relationship between exchange consolidation and returns volatility, Ben Slimane (2012) find that there is no significant impact of consolidation on volatility. This study contributes to the literature by finding the relationship between the demutualization and liquidity of listed firms, which is overlooked by literature.

\section{Hypothesis Development}

Abundant literature exists on the effect of demutualization on different outcomes, but these studies are only confined to the theory of the firm. Most of the previous studies discuss financial performance, efficiency, or social welfare issues (e.g., Azzam, 2010; Ben Slimane \& Padilla Angulo, 2017; Padilla-Angulo \& Ben Slimane, 2018; Serifsoy, 2008). There is scarce literature that analyzes demutualization from investors and listed firms' perspective. Moreover, many theoretical models explain investment and shareholders' behavior. However, not much is known about how demutualization affects investment decisions.

Nielsson (2009) suggested that firms can gain stock liquidity from demutualization due to several reasons. First, after demutualization, the market may be broadened due to which there may be a larger number of participants in the market trading in the stocks of listed firms. Eventually, as a result of the increase in the number of market participants, every firm will deal with a larger number of investors. Second, after demutualization, the market may deepen, which means that a large number of stocks are available for investors at prices slightly different from the existing market price. As individual and large trades are now unable to move prices, this will make the market more liquid. Third, firms may gain liquidity from demutualization because, after demutualization, transaction costs may be reduced. Transaction cost is reduced due to the merger of clearing and trading systems and an increase in trading volume. The European Commission estimated that after the merger of the stock exchange, 2 to 5 million euros could be saved that is spent on clearing and trading (Economist, 2006). It is expected that trading volume could be increased after demutualization because of the reduction in transaction costs. This study focuses on whether Pakistan Stock Exchange (PSX) has attracted volume after demutualization.

Based on these arguments, it can be hypothesized that the liquidity of listed firms might increase after demutualization. Therefore, we propose the following hypothesis:

H1: Demutualization positively influences the liquidity of listed firms' stocks.

\section{Methodology}

\section{Data and sample}

To compute different variables used in the analysis, this study obtained data from different sources. Data regarding stock prices and turnover is obtained from khistocks, which is an online website dealing with companies' stock prices and other financial information. Our panel consists of yearly observations from 2005 to 2017. Pakistan Stock Exchange that is demutualized in 2012 is the focus of this study. Our sample includes one hundred thirty-seven non-financial firms listed on it. The panel also includes some control variables in 
which prior literature suggests that it may affect liquidity. These variables include some firm-specific variables whose data is obtained from the financial reports of the firms. We also controlled for GDP per capita, and its data is obtained from the World Bank's database.

The outcome variable of this study is liquidity, which can be calculated in different ways. A commonly used proxy for liquidity is trading volume, which can be defined as the number of shares of a company traded on the stock exchange over a particular period. Another proxy for liquidity is Turnover, which is used as the main variable in this study. Turnover is measured as the number of shares of a company traded over a particular time divided by the number of shares outstanding. It is considered a better measure of liquidity because it not only takes trading volume into account but also the number of outstanding shares.

Trading activity, transaction cost, and market impact are different dimensions of liquidity. Turnover captures the trading dimension of liquidity that tells us about the trading activity of stocks of particular firms. This study aims to explore whether the amount of trading of listed firms' stock is increased after demutualization or not? The turnover dimension of liquidity exactly answers this. However, following Nielsson (2009), we also included the market impact and transaction cost dimensions of liquidity in our study. These are measured by the Amivest ratio and the bid-ask spread, respectively.

\section{Liquidity Measures}

Turnover, which is the main variable of our study, measures the trading activity of the firm's shares. However, we are interested in having a broader view of liquidity. For this purpose, two other dimensions of liquidity are taken into account. These two dimensions are transaction costs and market impact. Bid-ask spread captures the transaction cost dimension, while the Amivest ratio captures the market impact dimensions of liquidity (Nielsson, 2009).

\section{Amivest Ratio}

The market depth dimension of liquidity is captured and measured by the Amivest ratio. It measures how trading affects the market price of shares. This ratio is related to the marketability of stocks, that is, selling a great number of stocks without any significant price changes. Low price sensitivity is negatively related to liquidity and hence, will reduce uncertainty in the market place (Nielsson, 2009). Among others, Berkman and Eleswarapu (1998), Amihud, Mendelson, and Lauterbach (1997), and Cooper, Groth, and Avera (1985) used the Amivest ratio as a measure of stock liquidity. Amivest ratio is calculated as,

$$
\text { Amivest }_{i t}=\frac{\sum_{t=1}^{N} V_{i t}}{\sum_{t=1}^{N}\left|R_{i t}\right|}
$$

Where Amivest $t_{i t}$ is the Amivest ratio of $i$ firm at time $t . V_{\mathrm{it}}$ is the trading volume, and $\left|\mathrm{R}_{\mathrm{it}}\right|$ is the absolute returns of $i$ th firm at time $t$. $\mathrm{N}$ denotes each month trading days.

Table 1 - Variables definition

\begin{tabular}{|c|c|c|}
\hline Notation & Name of variable & Definition \\
\hline \multicolumn{3}{|c|}{$\begin{array}{l}\text { Panel 1: Dependent Variable } \\
\text { (Stock Liquidity) }\end{array}$} \\
\hline Turnover & Turnover & $\begin{array}{l}\text { A number of shares of a company traded over a } \\
\text { particular time divided by the number of shares } \\
\text { outstanding. }\end{array}$ \\
\hline Amivest & Amivest Ratio & Trading volume divided by absolute returns \\
\hline Bid-Ask Spread & Bid-Ask Spread & Difference between bid and ask prices quotes \\
\hline
\end{tabular}


Panel 2: Independent Variable

\section{Demutualization Demutualization}

Panel 3: Control Variables

\begin{tabular}{|c|c|c|}
\hline ROA & Return of Assets & Net income divided by total assets \\
\hline Price & Share price & Market price of firm stocks \\
\hline Leverage & Leverage & $\begin{array}{l}\text { Book value of firm total liabilities divided by } \\
\text { book value of total assets }\end{array}$ \\
\hline Size & Firm Size & Book value of firm's total assets \\
\hline SD & Volatility of Returns & Standard deviation of firms stock returns \\
\hline GDP & Gross Domestic Product & $\begin{array}{l}\text { Total value of goods and services produced in } \\
\text { one year }\end{array}$ \\
\hline Crisis & $\begin{array}{l}\text { Dummy variable for } \\
\text { financial crisis }\end{array}$ & $\begin{array}{l}\text { Dummy variable that takes } 0 \text { before } 2008 \text { and } 1 \\
\text { otherwise }\end{array}$ \\
\hline
\end{tabular}

This table reports the definitions of variables used in this study. Panel 1 lists dependent variables; Panel 2 lists independent variables, and Panel 3 lists control variables.

For a given month Amivest ratio measures the average trading volume of absolute returns. The higher the Amivest ratio, the more investors can trade without any significant price changes. Hasbrouck (2005) argued that the sample distribution of the Amivest ratio consists of outliers, so we follow the rule of thumb to take the natural $\log$ of the said variable.

\section{Bid-Ask Spread}

The cost dimension of liquidity is measured by the bid-ask spread. Transaction cost is measured through the difference between the bid and ask quotes. Bid-ask spread is calculated as,

$$
\text { Spread }_{i t}=\frac{a s k-\text { bid }}{((a s k+b i d) / 2)}
$$

Where Spread is the ask-bid spread, while ask and bid are the ask and bid quotes, respectively. Different estimators are available in the literature to calculate bid-ask spread, i.e. Roll (1984), Thompson and Waller (1986), and Hasbrouck (2004). We used Thompson and Waller (1986) estimator in our study as it is used by various researchers to estimate spread (Bryant \& Haigh*, 2004; Ma, Peterson, \& Sears, 1992; Thompson, Eales, \& Seibold, 1993). Thompson-Waller spread is calculated as,

$$
T W=\frac{1}{T} \sum_{t=1}^{T}\left|\Delta P_{t}\right|
$$

where TW is Thompson Waller spread, T is a non-zero price change, and $\mathrm{P}$ is the stock price.

\section{Model specification}

We conducted a two-step analysis. First, we performed univariate analysis to find whether liquidity is improved after demutualization. We find the difference between means of the three dimensions of liquidity before and after demutualization. We performed a t-test to know whether these pre and post-demutualization means are significantly different. Second, we explore the impact of demutualization on liquidity. For this purpose, we propose three equations. First, we find how the trading activity is affected by demutualization, which is the main purpose of this paper. We use turnover as a proxy for trading activity. Fixed-effect regression is employed to find whether the liquidity of listed firms is affected by demutualization. The estimated model is, 


$$
\begin{gathered}
\text { Turnover }_{i t}=\alpha+\beta_{1} \text { Demutualization }_{+} \beta_{2} \text { ROA }_{i t}+\beta_{3} \text { Price }_{i t}+\beta_{4} \text { Leverage }_{i t}+\beta_{5} M C A P_{i t}+\beta_{6} S D_{i t}+ \\
\beta_{7} G D P+\beta_{8} \text { Crisis }+\varepsilon_{i t}
\end{gathered}
$$

where Turnover $_{i t}$ is the measure of liquidity for the $i t h$ firm at time $t$. Demutualization is a dummy variable that takes 0 value before demutualization (in our case, the year of demutualization is 2012) and 1 otherwise. A number of control variables are also included in this study that the literature suggests can affect stock liquidity. These variables are ROA, share prices, leverage, market capitalization, the standard deviation of returns, and GDP. We also include the control variable for the global financial crisis of 2008. All these variables are defined in Table 1.

To know whether the market impact dimension of liquidity is affected by demutualization, we estimate equation (2). We have to find whether the market has deepened after demutualization. For this purpose, we specify the following model,

$$
\begin{gathered}
\text { Amivest }_{i t}=\alpha+\beta_{1} \text { Demutualization }+\beta_{2} \text { ROA }_{i t}+\beta_{3} \text { Price }_{i t}+\beta_{4} \text { Leverage }_{i t}+\beta_{5} M C A P_{i t}+\beta_{6} S D_{i t}+ \\
\beta_{7} G D P+\beta_{8} \text { Crisis }+\varepsilon_{i t}
\end{gathered}
$$

where Amivest $t_{i t}$ is the Amivest ratio of $i t h$ firm at time $t$.

To get a broader view of liquidity, we also investigate the cost dimension of liquidity. We analyze whether transaction cost is reduced after demutualization. To find this relationship, we estimate the following equation,

$$
\begin{gathered}
\text { Spread }_{i t}=\alpha+\beta_{1} \text { Demutualization }+_{+} \\
\beta_{2} \text { ROA }_{i t}+\beta_{3} \text { Leverage }_{i t}+\beta_{4} M C A P_{i t}+\beta_{5} S D_{i t}+\beta_{6} G D P+ \\
\beta_{7} \text { Crisis }+\varepsilon_{i t}
\end{gathered}
$$

where Spread $_{i t}$ is Thompson and Waller (1986) bid-ask spread.

To find the impact of demutualization on liquidity, we estimate the unbalanced panel data model. We use Hausman (1978) statistic to choose between fixed and random-effect models. Hausman test finds whether there is any association between unobserved firm-specific random effect and the regressors. If this correlation is significant, we conclude that the fixed-effect model is more appropriate. However, if there is no significant correlation, then we conclude that the random-effect model is parsimonious and appropriate. Table 2 reports the results of the Hausman test, which suggests that the fixed effect model is consistent.

\section{Table 2 - Hausman specification test}

\begin{tabular}{ll}
\hline & Coef. \\
\hline Chi-square test value & 113.784 \\
P-value & 0.000 \\
\hline
\end{tabular}

This table reports the results of the Hausman test for model appropriateness. The Chi-square statistic and p-value are reported.

\section{Results}

\section{Descriptive statistics}

Table 3 shows descriptive statistics of all variables included in this study except demutualization, which is a dummy variable. The table gives the number of observations $(\mathrm{N})$, mean, standard deviation (sd), minimum (min), and maximum (max) values of all variables. All these variables are defined in Table 1. 
Table 3 - Descriptive Statistics

\begin{tabular}{llllll}
\hline VARIABLES & $\begin{array}{l}\text { Number of } \\
\text { observations }\end{array}$ & Mean & $\begin{array}{l}\text { Standard } \\
\text { Deviation }\end{array}$ & Min & Max \\
\hline Turnover & 1,759 & 16.02 & 3.051 & 4.605 & 23.61 \\
ROA & 1,338 & 6.981 & 13.10 & -163.3 & 67.96 \\
Prices & 1,760 & 260.7 & 867.3 & 0.650 & 11,500 \\
Leverage & 1,336 & 0.520 & 0.299 & 0.00592 & 3.318 \\
Size & 1,338 & 22.91 & 1.506 & 18.17 & 27.16 \\
SD & 1,761 & 3.377 & 1.758 & 0.849 & 7.599 \\
GDP & 1,761 & 16.57 & 0.487 & 15.72 & 17.22 \\
Amivest & 1,753 & 17.19 & 3.241 & 1.057 & 27.41 \\
Spread & 1,616 & 10.26 & 0.976 & 5.368 & 13.93 \\
\hline
\end{tabular}

This table represents the descriptive statistic of all dependent and control variables. Turnover, Amivest, and Spread are dependent variables that all others are control variables. The sample includes yearly values for the period of 2005 to 2017 . We excluded our independent variables (demutualization) from this table because that is a dummy variable that has only 0 and 1 value.

There is not a big difference between the maximum and minimum values for all variables, which means that there are no extreme values. To visualize the trend of our dependent variables, a line graph is shown in Figure 1 - Liquidity Trend. A general trend of the three proxies of our dependent variables is depicted in figure 1 for the whole sample. The blue line represents turnover, which is our main variable in this study. Other proxies of liquidity, which are the Amivest Ratio and Bid-Ask spread, are represented by red and black lines, respectively. The vertical dotted line represents the year of demutualization, which is 2012 in our case. Figure 1 shows that turnover has been increased after demutualization. Before demutualization, not only turnover is low but also has some sharp ups and downs. While after demutualization, the line does not show any sharp ups and downs. It seems that liquidity risk is minimized up to some extent after demutualization. Figure 1 shows the same trend for the Amivest ratio, while the spread has reduced. Reduced spread means increased liquidity. Overall, Figure 1 - Liquidity Trend tells us that the liquidity of stocks has been increased after demutualization.

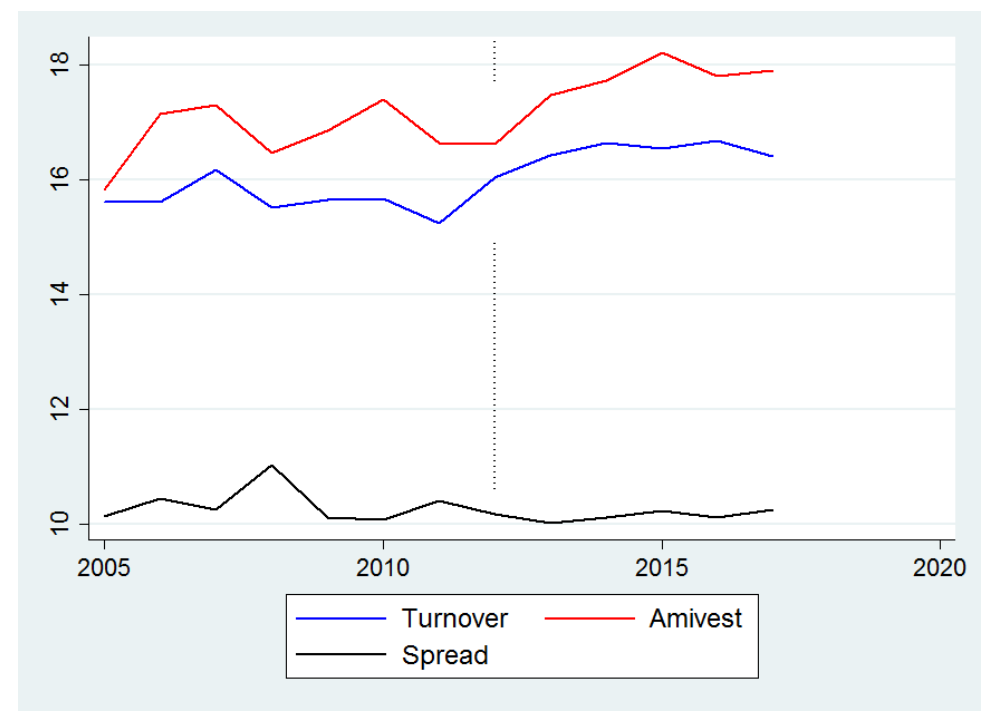

Figure 1 - Liquidity Trend

This figure shows the liquidity trend of stocks of listed firms from 2005 to 2017. The red line represents the Amivest ratio, the blue line represents the bid-ask spread, the black line represents turnover, and the vertical dashed line represents the year of demutualization, which is 2012 . 
Table 4 - Differences in the mean of the three dimensions of liquidity

\begin{tabular}{llllll} 
& $\begin{array}{l}\text { Before } \\
\text { Demutualization }\end{array}$ & $\begin{array}{l}\text { After } \\
\text { Demutualization }\end{array}$ & Difference & t_value & p_value \\
\hline Turnover & 15.64 & 16.543 & -.903 & -5.9 & 0.000 \\
Amivest & 16.813 & 17.831 & -1.019 & -6.3 & 0.000 \\
Spread & 47675.78 & 34259.97 & 13415.81 & 5.1 & 0.000 \\
\hline
\end{tabular}

This table provides means of all the three dimensions of liquidity before and after demutualization. The difference is calculated as "mean after demutualization" minus "mean before demutualization". The last two columns report t-value and p-value.

\section{Univariate Analysis}

Table 4 shows the results of the univariate analysis. The mean values of the three variables, which captures all the three dimensions of liquidity are given before and after demutualization. We find that trading activity is significantly increased from 15.64 to 16.543 after demutualization. Considering the second dimension of liquidity, which the Amivest ratio, we find that this ratio is increased from 16.813 to 17.831. This tells us that the market has significantly deepened after demutualization. We observe that the bid-ask spread has reduced from 47675.78 to 34259.97 after demutualization. This means that spread has narrowed down, and transaction cost is significantly reduced by demutualization. Summing up the univariate analysis, we conclude that stock liquidity is improved after demutualization.

\section{Multivariate Analysis}

Table 5 reports the results of fixed-effect regression for all the three equations of our study. Turnover is used as a measure of liquidity in this study. We tested whether demutualization enhances firms' stock liquidity? 'This is answered in column (1) of Table 5.

Interestingly, demutualization significantly affects turnover. Hence, the liquidity of the average firm has increased with demutualization. These results are consistent with Padilla and Pagano (2005) and Nielsson (2009). The reason behind this increase in stock liquidity is that the market has become efficient after demutualization (Serifsoy, 2008). Demutualization also reduces transaction cost and has resulted in increased market share (Arnold, Hersch, Mulherin, \& Netter, 1999). As a result of enhanced efficiency, greater market share, and reduced transaction cost, more and more

Table 5 - Fixed-Effect Regression Results

\begin{tabular}{llll}
\hline & $\mathbf{( 1 )}$ & $\mathbf{( 2 )}$ & $\mathbf{( 3 )}$ \\
\hline VARIABLES & Turnover & Amivest & Spread \\
Demutualization & $1.613^{* * *}$ & $1.157^{* * *}$ & $-0.430^{* * *}$ \\
ROA & $(0.169)$ & $(0.221)$ & $(0.023)$ \\
& $0.006^{*}$ & 0.152 & -0.040 \\
Prices & $(0.003)$ & $(0.454)$ & $(0.053)$ \\
& $-0.000^{* * *}$ & $-0.000^{* * *}$ & \\
Leverage & $(0.000)$ & $(0.000)$ & 0.031 \\
Size & 0.283 & 0.410 & $(0.037)$ \\
SD & $(0.261)$ & $(0.340)$ & -0.003 \\
& -0.007 & 0.125 & $(0.017)$ \\
GDP & $(0.124)$ & $(0.162)$ & $0.020^{*}$ \\
& $-0.160^{*}$ & $-0.420^{* * *}$ & $(0.012)$ \\
& $(0.085)$ & $(0.111)$ & $0.713^{* * *}$ \\
\end{tabular}




\begin{tabular}{llll}
\hline crisis & $0.379 * *$ & $0.844^{* * *}$ & $-1.067 * * *$ \\
& $(0.164)$ & $(0.214)$ & $(0.023)$ \\
Constant & $39.929 * * *$ & $43.415^{* * *}$ & -0.478 \\
& $(7.443)$ & $(9.729)$ & $(1.040)$ \\
Observations & 1,197 & 1,194 & 1,122 \\
R-squared & 0.192 & 0.128 & 0.756 \\
\hline
\end{tabular}

This table reports the results of the Fixed-Effect panel model. The dependent variables are turnover (Turnover), Amivest ratio (Amivest), and bid-ask spread (Spread). Standard errors are reported in parentheses. *** mean $\mathrm{p}<0.01$, ** mean $\mathrm{p}<0.05$, and $*$ mean $\mathrm{p}<0.1$. All variables are defined in Table 1 .

participants are now involved in trading activity. This increases the stock turnover of the listed firms. We controlled for some firm-specific and macroeconomic variables. Results in column (1) of Table 5 show that ROA and crisis have a positive and significant impact on turnover, which is in line with Alves, Canadas, and Rodrigues (2015). Investors may be interested in buying the stocks of firms that have higher profitability. This will increase the trade of the firm's stocks, resulting in an increase in stock liquidity. Stock prices, the volatility of returns, and GDP have a negative and significant relationship with turnover. We found that leverage and firm size have no significant impact on liquidity.

The first section of our study shows that demutualization has increased trading volume for average firms. This resulted in an increase in trading activity, which ultimately increased firms' stock liquidity. This directly answered our question of whether more participants are trading on the stock exchange after demutualization. We are also interested in exploring other dimensions of liquidity, that is, the transaction cost of trading, how much time it will take to complete a transaction, and how much it affects the prices. Column (2) of Table 5 reports the regression results of our second measure of liquidity, which is the Amivest ratio. The coefficient of the Amivest ratio is positive and significant, which means that the market has deepened after demutualization. Investors can trade in a larger volume of shares without greater changes in stock prices. These results are consistent with Nielsson (2009). Results for market activity (measured by turnover) are the same as market depth (measured by the Amivest ratio). This means that demutualization has not only increased liquidity but also enhanced the market depth of stocks of firms listed on these demutualized exchanges.

Column (3) of Table 5 reports the results of the impact of demutualization on the bid-ask spread. Results show that bid-ask spread has been narrowed down by demutualization, which implies that the transaction cost has reduced after demutualization. These results are consistent with previous studies (Arnold et al., 1999; Padilla \& Pagano, 2005). Arnold et al. (1999) found that a reduction in the bid-ask spread was due to the merger of three stock exchanges in the United States. While Padilla and Pagano (2005) argued that reduction in the bid-ask spread was due to the unification of the clearing system after the merger. They find that bid-ask spread has been reduced by $27 \%$ due to the unification of the clearing system. In the current study, we also found a significant decrease in bid-ask spread by demutualization after controlling for firm-specific, market-specific, and some macroeconomic variables.

To sum up, demutualization has improved all types of liquidity measures. The main focus of our study was on trading activity (measured by turnover), that is, we try to find whether the trading activity has increased after demutualization and whether investors can now easily trade on the stock market. The data supported our hypothesis that trading activity has increased for the average firm. To get a broader view of liquidity, we also find that demutualization has improved market depth (Amivest Ratio) and transaction cost (bid-ask spread).

\section{Conclusion}

We investigate the impact of demutualization on the liquidity of listed firms' stocks. We find that demutualization has increased trading activity as the market has become broader after demutualization. More 
participants trade on the stock exchange due to which trading volume has been increased. We also investigate two other dimensions of liquidity, namely, the Amivest ratio and bid-ask spread. We find that demutualization significantly increases the Amivest ratio. As the Amivest ratio captures the market dimension of liquidity, we conclude that market depth has improved after demutualization. Finally, we find that the bid-ask spread is narrowed down by demutualization. Demutualization has reduced transaction costs due to which bid-ask spread has been narrowed down. We conclude that demutualization is beneficial not only for listed firms but also for its shareholders as all three dimensions of liquidity are improved by demutualization.

Funding: This research received no external funding.

Acknowledgments: We are thankful to the editiors and anonymous reviewrs whose useful comments improved this paper.

Conflicts of Interest: The authors declare no conflict of interest.

\section{References}

Aggarwal, R. (2002). Demutualization and corporate governance of stock exchanges.

Aggarwal, R., \& Dahiya, S. (2006). Demutualization and public offerings of financial exchanges. Journal of Applied Corporate Finance, 18(3), 96-106.

Alves, H., Canadas, N., \& Rodrigues, A. M. (2015). Determinants of Share Price and Share Liquidity: An Analysis Using a SEM Model. Procedia Economics and Finance, 25, 318-331.

Amihud, Y., \& Mendelson, H. (1986). Liquidity and stock returns. Financial Analysts Journal, 42(3), 43-48.

Amihud, Y., Mendelson, H., \& Lauterbach, B. (1997). Market microstructure and securities values: Evidence from the Tel Aviv Stock Exchange. Journal of financial Economics, 45(3), 365-390.

Angel, J. J. (2003). Discussion of "Stock exchange governance and market quality" by Krishnamurti, Sequeira, and Fangjian. Journal of banking \& finance, 27(9), 1879-1881.

Arnold, T., Hersch, P., Mulherin, J. H., \& Netter, J. (1999). Merging markets. The Journal of finance, 54(3), 10831107.

Azzam, I. (2010). Stock exchange demutualization and performance. Global Finance Journal, 21(2), 211-222.

Ben Slimane, F. (2012). Stock exchange consolidation and return volatility. Managerial Finance, 38(6), 606-627.

Ben Slimane, F., \& Padilla Angulo, L. (2017). The impact of demutualization on stock exchanges' financial performance: the moderating role of corporate governance practices. Retrieved from

Berkman, H., \& Eleswarapu, V. R. (1998). Short-term traders and liquidity:: a test using Bombay Stock Exchange data. Journal of financial Economics, 47(3), 339-355.

Bryant, H. L., \& Haigh*, M. S. (2004). Bid-ask spreads in commodity futures markets. Applied Financial Economics, 14(13), 923-936.

Cooper, S. K., Groth, J. C., \& Avera, W. E. (1985). Liquidity, exchange listing, and common stock performance. Journal of Economics and Business, 37(1), 19-33.

Cybo-Ottone, A., Di Noia, C., \& Murgia, M. (2000). Recent development in the structure of securities markets. Brookings-Wharton papers on financial services, 2000(1), 223-273.

Datar, V. T., Naik, N. Y., \& Radcliffe, R. (1998). Liquidity and stock returns: An alternative test. Journal of Financial Markets, 1(2), 203-219.

Economist. (2006, 27 May). Special Report on Financial Exchanges. Battle of the bourses., 65-67.

Hart, O., \& Moore, J. (1996). The governance of exchanges: members' cooperatives versus outside ownership. Oxford review of economic policy, 12(4), 53-69.

Hasbrouck, J. (2004). Liquidity in the futures pits: Inferring market dynamics from incomplete data. Journal of Financial and Quantitative Analysis, 39(2), 305-326. 
Hasbrouck, J. (2005). Trading costs and returns for US equities: The evidence from daily data. NYU Stern School Department of Finance Working Paper.

Hausman, J. A. (1978). Specification tests in econometrics. Econometrica: Journal of the econometric society, 12511271.

Hughes, P. S., \& Zargar, E. (2006). Exchange demutualization. Paper presented at the APEC Financial Regulators Training Initiative Regional Seminar Demutualization of Exchange, Manila.

Karmel, R. (2000). Demutualization: Implications for the Regulation and Governance of Securities Exchanges. Paper presented at the 25th IOSCO Annual Conference.

Krishnamurti, C., Sequeira, J. M., \& Fangjian, F. (2003). Stock exchange governance and market quality. Journal of banking \& finance, 27(9), 1859-1878.

Lee, R. (1998). What is an exchange?: Automation, management, and regulation of financial markets: OUP Oxford.

Ma, C. K., Peterson, R. L., \& Sears, S. (1992). Trading Noise, Adverse Selection, and Intraday BidAsk Spreads in Futures Markets. The Journal of Futures Markets (1986-1998), 12(5), 519.

Nielsson, U. (2009). Stock exchange merger and liquidity: The case of Euronext. Journal of Financial Markets, 12(2), 229-267.

Otchere, I., \& Abou-Zied, K. (2008). Stock exchange demutualization, self-listing and performance: The case of the Australian Stock Exchange. Journal of banking \& finance, 32(4), 512-525.

Padilla-Angulo, L., \& Ben Slimane, F. (2018). Board restructuring and successful demutualization: the stock exchanges. Journal of Organizational Change Management, 31(3), 598-618.

Padilla, A., \& Pagano, M. (2005). Efficiency Gains from the Integration of Stock Exchanges: Lessons from the Euronext "Natural Experiment". A report for Euronext.

Roll, R. (1984). A simple implicit measure of the effective bid-ask spread in an efficient market. The Journal of finance, 39(4), 1127-1139.

Schmiedel, H. (2001). Technological development and concentration of stock exchanges in Europe.

Schmiedel, H. (2002). Total factor productivity growth in European stock exchanges: A non-parametric frontier approach.

Serifsoy, B. (2008). Demutualization, outsider ownership, and stock exchange performance: empirical evidence. Economics of Governance, 9(4), 305.

Slimane, F. B., \& Angulo, L. P. (2018). Strategic change and corporate governance: Evidence from the stock exchange industry. Journal of Business Research.

Steil, B. (2002). Changes in the ownership and governance of securities exchanges: causes and consequences. Brookings-Wharton papers on financial services, 2002(1), 61-91.

Thompson, S., Eales, J. S., \& Seibold, D. (1993). Comparison of liquidity costs between the Kansas City and Chicago wheat futures contracts. Journal of Agricultural and Resource Economics, 185-197.

Thompson, S., \& Waller, M. (1986). The Execution Cost of Trading in Commodity Futures Markets. 